\title{
EKSISTENSI PEREMPUAN DALAM NOVEL SEMPURNA KARYA NOVANKA RAJA: KAJIAN FEMINISME EKSISTENSIALIS
}

\author{
Risma Khairun Nisya ${ }^{1}$, Andina Dwi Komalasari ${ }^{2}$ \\ ${ }^{1}$ Universitas Majalengka, rismakhairunnisya@unma.ac.id \\ ${ }^{2}$ Universitas Majalengka, andinadwik98@gmail.com
}

\begin{abstract}
ABSTRAK
Penelitian ini mengkaji novel berjudul Sempurna karya Novanka Raja dengan pendekatan feminisme eksistensialis. Feminisme eksistensial memandang peran perempuan dalam menunjukkan eksistensinya, karena sebagai perempuan tidak harus selalu bergantung kepada laki-laki. Metode dalam penelitian ini yaitu deskriptif kualitatif dengan peneliti sebagai instrument kunci dan analisis isi. Sumber data penelitian adalah novel Sempurna karya Novanka Raja dengan menganalisis eksistensi tokoh utama perempuannya, serta bagaimana pengaruh tokoh laki-laki terhadap tokoh utama perempuan. Hasil penelitian membahas relasi tokoh laki-laki yaitu bagaimana laki-laki tersebut mampu mengubah kehidupannya, seperti 1) cinta mampu mengubah penampilan diri; 2) cinta mampu mengubah segalanya; 3) terluka kembali; 4) cinta dan keyakinan. Sedangkan eksistensi perempuan merupakan bagaimana perempuan tersebut bisa bereksistensi, yang sadar akan dirinya dan tahu cara menempatkan dirinya, meliputi 1) perempuan yang mandiri dan pekerja keras; 2) perempuan yang kuat; 3) perempuan yang teguh pendirian; 4) perempuan yang penuh keyakinan; 5) perempuan yang percaya bahwa Tuhan akan memberikan yang terbaik.
\end{abstract}

\section{Kata kunci : Feminisme eksistensialis, novel Sempurna.}

How to Cite: Nisya, Risma Khairun \& Andina Dwi Komalasari. (2020). "Eksistensi Perempuan dalam Novel Sempurna Karya Novanka Raja: Kajian Feminisme Eksistensialis." Bahtera Indonesia: Jurnal Penelitian Pendidikan Bahasa dan Sastra Indonesia, Vol. 5, No. $2,165-175$.

DOI: https://doi.org/10.31943/bi.v5i2.89

\section{PENDAHULUAN}

Karya sastra merupakan hasil rekaan yang diciptakan pengarang melalui imajinasinya. Novel merupakan salah satu bentuk karya sastra yang saat ini banyak digemari oleh masyarakat. Selain dapat dijadikan bahan pembelajaran sastra di Sekolah, novel dapat menjadi sumber pendidikan karakter bagi pembacanya. Saat ini, banyak novel yang mengangkat kisah hidup dan perjuangan perempuan dalam melawan ketidakadilan. Novel tersebut memberikan gambaran pada pembaca bahwa masih banyak perempuanperempuan yang merasakan ketidakadilan dalam menjalani kehidupannya. Dalam penelitian ini, peneliti mengkaji Novel 
berjudul Sempurna Karya Novanka Raja dengan pendekatan feminism eksistensialis.

Pendekatan feminism merupakan kajian yang membahas mengenai perempuan tentang bagaimana perempuan tersebut melawan adanya ketidakadilan dalam hidupnya. Eksistensialisme memandang manusia sebagai suatu makhluk yang harus bereksistensi, mengkaji cara manusia berada di dunia dengan kesadaran. Manusia menjadi pusat eksistensiaslime, karena manusia bertanggung jawab terhadap dirinya sendiri. Manusia berhak memilih apa yang akan dia lakukan guna menunjukkan keberadaan dirinya. Hal ini sejalan dengan pendapat Hidayat (2013: 3) eksistensialisme memandang manusia sebagai suatu yang tinggi, dan keberadaannya itu selalu ditentukan oleh dirinya, karena hanya manusialah yang dapat bereksistensi, yang sadar akan dirinya dan tahu cara menempatkan dirinya.

Novel Sempurna karya Novanka Raja menceritakan ketegaran tokoh utama perempuan bernama Clarissa. Clarissa merupakan gadis berusia 28 tahun tetapi masih jomlo. Dia sangat sulit membuka hatinya untuk orang lain, hingga pada akhirnya dia bertemu dengan Arka. Arka mampu mengubah hidupnya menjadi lebih berwarna, meskipun mereka tidak jadian tetapi keduanya sangat saling mencintai. Hal itu terlihat dari sikap Arka kepada Clarissa begitupun sebaliknya. Tetapi pada suatu hari, Clarissa menemukan foto Arka dengan wanita lain di dalam mobilnya, ternyata wanita itu adalah tunangannya. Kejadian itu membuat Clarissa sangat kecewa dan sedih. Dia kembali merasakan luka. Padahal, dia sudah sangat percaya bahwa Arka adalah lelaki yang Tuhan kirimkan untuknya, tetapi itu salah. Clarissa mencoba untuk tidak berlarutlarut dalam kesedihan, meskipun Arka terus mencoba agar Clarissa mau memaafkannya tetapi itu tidak membuat
Clarissa goyah. Clarissa kembali lagi membuka hati, meskipun sulit tetapi dia percaya bahwa Tuhan akan memberikan yang terbaik untuknya. Hidup Clarissa kembali berwarnasetelah ia bertemu Reza, teman kantornya. Reza mengubah hidup Clarissa, mengubah luka menjadi cinta, dan Reza mampu meyakinkan Clarissa hingga Clarissa percaya bahwa Reza adalah jodoh yang Tuhan kirimkan untuknya yang akan menyempurnakan hidupnya.

Adapun penelitian sebelumnya yang relevan dengan penelitian ini adalah penelitian berjudul Representasi Perempuan dalam Novel Supernova-Petir karya Dewi Lestari : Kajian Feminisme Eksistensialis oleh Andrian Risqy Hidayat, dkk. Dalam penelitian ini mengkaji novel Supernova-Petir karya Dewi Lestari berdasarkan kajian feminisme eksistensialis. Adapun hasil dari penelitian ini yaitu peneliti menitikberatkan pada relasi kuasa laki-laki dan perempuan, eksistensi tokoh perempuan, dan representasi perempuan. Relasi kuasa yang terjadi adalah peran laki-laki dalam pengembangan potensi, perempuan domestik dan pemenuhan kebutuhan materi, perempuan karir, dan pelecehan terhadap perempuan.

Feminisme eksistensial memandang peran perempuan dalam menunjukkan eksistensinya. Sebagai perempuan tidak harus selalu bergantung kepada laki-laki. Ketika adanya ketidakadilan, perempuan berhak menentukan tindakan yang harus dia lakukan. Seperti dalam novel Sempurna karya Novanka Raja. Clarissa, tokoh utama perempuan dalam novel ini, dia mengalami kisah cinta yang begitu rumit. Tetapi, Clarissa adalah sosok perempuan yang kuat, mandiri, dan tidak selalu bergantung pada orang lain termasuk pada Arka, tokoh laki-laki yang sangat dia cintai tetapi ternyata Arka mengkhianati Clarissa. Clarissa menjalani hidupnya dengan penuh ketegaran, karena dia yakin Tuhan akan memberikan jodoh yang terbaik untuknya. 
Untuk memperdalam mengenai kajian feminisme, peneliti mengkajinya pada novel Sempurna karya Novanka Raja dan mengangkatnya dalam judul Eksistensi Perempuan dalam novel Sempurna Karya Novanka Raja : Kajian Feminisme Eksistensialis.

\section{Kajian Teori}

\section{Novel}

Kata novel berasal dari bahasa Latin novellus. Kata novellus dibentuk dari kata novus yang berarti baru atau new dalam bahasa Inggris. Dikatakan baru karena bentuk novel adalah bentuk karya sastra yang datang kemudian dari karya sastra lainnya, yaitu puisi dan drama. Kehadiran bentuk novel sebagai salah satu bentuk karya sastra berawal dari kesusastraan Inggris, pada awal abad ke-18. Timbulnya akibat pengaruh tumbuhnya filsafat yang dikembangkan John Locke (1632-1704) yang menekankan pentingnya fakta atau pengalaman dan bahayanya berpikir secara fantastis (Priyatni, 2015: 124).

Adapun novel bentuknya lebih panjang (setidaknya 40.000 kata) dan lebih kompleks daripada cerpen, tidak dibatasi keterbatasan struktural dan metrikal sandiwara dan sajak. Umumnya sebuah novel bercerita tentang tokoh-tokoh dan kelakuan atau watak mereka dalam kehidupan sehari-hari, dengan menitik beratkan pada sisi-sisi yang aneh dari naratif tersebut (Warsiman, 2016: 109).

Berdasarkan pengertian di atas, dapat disimpulkan bahwa novel merupakan karangan prosa fiksi yang mengangkat suatu kejadian atau peristiwa yang biasanya terjadi dalam kehidupan seharihari dengan alur yang cukup panjang dan dengan menonjolkan watak dari setiap tokohnya.

\section{Kajian Feminisme}

Secara etimologis feminis berasal dari kata femme (woman) berarti perempuan (tunggal) yang bertujuan untuk memperjuangkan hak-hak perempuan sebagai kelas sosial. Dalam hubungan ini perlu dibedakan antara male dan female (sebagai aspek perbedaan biologis, sebagai hakikat alamiah), masculine danfeminime (sebagai aspek perbedaan psikologis dan struktural). Dengan kata lain, masculine, feminime ditentukan secara kultural, sebagai hasil pengaturan kembali infrastuktur material dan superstruktur ideologis. Feminitas adalah pengertian psikologis struktural seseorang yang tidak dilahirkan sebagai perempuan melainkan menjadi perempuan. Oleh karena itu, hal yang ditolak oleh kelompok feminis adalah anggapan bahwa perempuan adalah konstruksi negatif, perempuan sebagai makhluk takluk, perempuan yang terjerat ke dalam dikotomi sentral marginal, superior, interior (Ratna, 2007: 184-185).

Fakih (2001: 99) berpendapat bahwa feminisme merupakan gerakan yang pada mulanya berangkat dari asumsi bahwa kaum perempuan pada dasarnya tidak mau ditindas dan dieksploitasi, serta usaha untuk mengakhiri penindasan dan eksploitasi tersebut. Hakikat perjuangan feminisme ialah untuk kesamaan martabat dan kebebasan mengontrol raga dan kehidupan, baik di dalam maupun di luar rumah.

Budianta (dalam Dina, dkk, 2013: 3) mengartikan feminisme sebagai suatu kritik ideologis terhadap cara pandang yang mengabaikan permasalahan ketimpangan dan ketidakadilan dalam pemberian peran dan identitas sosial berdasarkan perbedaan jenis kelamin. Feminisme pada dasarnya merupakan sebuah topik pembicaraan wanita dengan mengikutsertakan pria sebagai mahluk yang selalu dicemburui, sebagai mahluk yang superior (kuat), yang senantiasa menganggap wanita sebagai mahluk yang inferior (lemah).

Jadi, dapat disimpulkan bahwa feminisme merupakan kajian yang membahas mengenai perempuan dan segala permasalahannya. Permasalahan tersebut bisa berupa ketidakadilan dalam hidupnya, serta adanya perbedaan yang dilihat dari jenis kelamin. 


\section{Feminisme Eksistensialis}

Eksistensialisme berasal dari kata eksistensi, kata dasarnya exist, yang bila diuraikan ex: keluar sistere: berdiri. Jadi, eksistensi berarti berdiri dengan keluar dan diri sendiri (Maksum, 2014: 363). Simone de Beaviour mengenalkan gerakan feminisme eksistensialis untuk mencapai tujuannya dengan konsep transendensi, yaitu ide tentang pelampauan. Menurutnya, terdapat empat strategi transendensi yang dapat dilakukan: (1) perempuan dapat bekerja, meskipun keras dan melelahkan; (2) perempuan dapat menjadi seorang intelek; (3) perempuan dapat bekerja untuk mencapai transformasi sosialis masyarakat; dan (4) perempuan dapat menolak keliyanannya dengan mengidentifikasikan diri melalui pandangan kelompok dominan dalam masyarakat.

Istilah eksistensialisme adalah suatu protes atas nama individualis terhadap konsep "akal" dan "alam" yang ditekankan pada periode Pencerahan (Enlightenment) pada abad ke-18. Eksistensiaslime adalah suatu filsafat yang melukiskan dan mendiagnosa kedudukan manusia yang sulit. Eksistensialisme sebagai suatu unsur yang universal dalam segala pemikiran adalah usaha manusia untuk melukiskan eksistensinya serta konflik-konflik eksistensinya (Suhar, 2010: 159)

Eksistensialisme memandang manusia sebagai suatu makhluk yang harus bereksistensi, mengkaji cara manusia berada di dunia dengan kesadaran. Pusat renungan eksistensialisme adalah manusia konkret. Dalam eksistensialisme selalu melihat cara manusia berada. Eksistensi diartikan secara dinamis sehingga ada unsur berbuat dan menjadi, manusia dipandang sebagai suatu realitas yang terbuka dan belum selesai, dan berdasarkan pengalaman yang konkret. Jadi dapat disimpulkan bahwa eksistensialisme memandang manusia sebagai suatu yang tinggi, dan keberadaannya itu selalu ditentukan oleh dirinya, karena hanya manusialah yang dapat bereksistensi, yang sadar akan dirinya dan tahu cara menempatkan dirinya (Hidayat, dkk. 2013: $3)$.

\section{METODE PENELITIAN}

Metode yang digunakan dalam penelitian ini adalah metode kualitatif. Menurut Sugiyono (2015: 15) penelitian kualitatif adalah penelitian yang berlandaskan pada filsafat postpositivisme, digunakan untuk meneliti pada kondisi obyek yang alamiah, dimana peneliti adalah sebagai instrumen kunci. Bentuk penelitian ini adalah analisis isi. Analisis isi adalah penelitian yang bersifat pembahasan secara mendalam terhadap isi suatu informasi. Adapun, sumber data penelitian ini adalah novel Sempurna karya Novanka Raja dengan tebal 180 halaman yang diterbitkan oleh Euthenia.

Penelitian ini mengkaji novel Sempurna karya Novanka Raja menggunakan pendekatan feminisme eksistensialis. Dalam penelitian ini, dikaji eksistensi tokoh utama perempuannya, serta bagaimana pengaruh tokohlaki-laki terhadap tokoh utama perempuan.

\section{HASIL DAN PEMBAHASAN}

Feminisme eksistensialis mengkaji bagaimana eksistensi tokoh perempuan dalam menjalani hidupnya. Tak jarang, tokoh perempuan itu mendapat pengaruh dari tokoh laki-laki. Hasil analisis yang diperoleh dalam novel Sempurna karya Novanka Raja meliputi bagaimana pengaruh tokoh laki-laki terhadap tokoh perempuan, karena dalam novel ini menceritakan tokoh perempuan yang begitu mencintai tokoh laki-laki tetapi pada akhirnya tokoh perempuan ini disakiti oleh tokoh laki-laki. Selain itu, analisis eksistensi tokoh perempuan dalam menjalani hidupnya. Sebagai perempuan, tidak harus selalu bergantung pada lakilaki. Perempuan juga mampu hidup mandiri, dan perempuan juga tidak 
selamanya lemah. Terlebih, ketika mengalami permasalahan dalam hidupnya, perempuan juga mampu menyelesaikan setiap permasalahan yang dialaminya dengan tegar. Berikut ini dipaparkan hasil analisis novel berjudul Sempurna karya Novanka Raja.

\section{Relasi Tokoh Perempuan dan Laki- Laki}

Relasi antara laki-laki dan perempuan merupakan tema yang tidak pernah kunjung usai. Persoalan menjadi semakin sulit ketika dalam relasi terjadi ketimpangan hubungan subordinasi. Bentuk pendobrakan perempuan atas kuasa laki-laki tidak terlepas dari sistem patriarki yang tidak adil yang menempatkan perempuan sebagai bayang-bayang lakilaki. Hubungan laki-laki dan perempuan dalam sistem patriarki tidak digambarkan sebagai hubungan dengan entitas masingmasing. Akan tetapi, salah satu entitas (perempuan) digambarkan identitasnya dalam hubungannya dengan laki-laki (Hidayat, dkk, 2013: 3).Adapun hasil analisis relasi tokoh perempuan dan lakilaki dalam novel Sempurna karya Novanka Raja ini yaitu:

1) Cinta Mampu Mengubah Penampilan Diri

Tokoh laki-laki dapat memberikan pengaruh dalam hidup tokoh perempuan. Terlebih, ketika tokoh perempuan itu mencintai tokoh lakilaki maka tokoh perempuan akan melakukan apapun agar tokoh lakilaki mencintainya. Salah satunya dengan mengubah penampilan diri. Berdasarkan hal tersebut, maka tokoh laki-laki memang dapat mempengaruhi tokoh perempuan dalam menjalani hidupnya.

Arka merupakan sosok lelaki yang mampu mengubah penampilan Clarissa. Hari itu, Arka mengajak Clarissa untuk kencan. Clarissa sebisa mungkin harus terlihat cantik saat bertemu dengan Arka. Dia berusaha untuk tampil cantik dan dibantu oleh kedua sahabatnya, yaitu Tere dan
Reyna. Kedua sahabatnya sibuk memilih gaun sekaligus aksesoris yang akan dikenakan Clarissa. Awalnya Clarissa menolak, tetapi akhirnya dia nurut juga karena dia merasa dia harus terlihat cantik di depan Arka. Hal itu terlihat dari dua kutipan berikut.

(1) Guyuran air shower benarbenar membuatku merasa sangat segar. Sinar matahari yang masuk melalui kaca yang ada di dalam kamar mandi membuatku makin bersemangat menyambut hari ini. hanya ada satu masalah, aku masih belum tahu harus mengenakan pakaian apa. Meski sejak kemarin sudah kubaca baik-baik apa yang ada di tips majalah, namun rasanya semua tak ada yang cocok untukku (Sempurna: 64).

(2) Meski awalnya aku merasa aneh, namun akhirnya aku pakai gaun itu juga. Reyna kini sibuk memilih aksesoris dari kotak aksesorisku. Ia lalu mengambil bros berwarna biru laut dengan dengan butir permata yang berkilauan, memasangkannya di baju yang kupakai hingga aku sedikit risih. Baju ini sejak kubeli memang belum pernah aku pakai, sekalinya dipakai ya saat mencobanya di butik tempat akumembeli (Sempuna 65).

Arka mampu mengubah Clarissa menjadi wanita yang lebih memperhatikan penampilannya. Hal itu dilakukan karena Clarissa ingin terlihat lebih cantik di depan Arka sehingga Arka akan merasa lebih tertarik dengan Clarissa. Hal tersebut terlihat pada data nomor (1) yang menunjukkan kebingungan Clarissa akan mengenakan pakaian apa. Dari data tersebut terlihat bahwa Clarissa 
ingin tampil secantik mungkin di depan Arka. Data pada nomor (1) diperkuat dengan data pada nomor (2) yang menunjukkan bahwa Clarissa benar-benar mengubah penampilannya. Hal ini menunjukkan adanya relasi tokoh laki-laki terhadap perempuan berupa cinta mampu mengubah penampilan diri.

2) Cinta Mengubah Segalanya

Clarissa merupakan gadis berusia 28 tahun tetapi masih jomlo. Namun, kehadiran Arka mampu mengubah segalanya, mengubah hidupnya menjadi lebih berwarna. Meskipun mereka belum jadian, tetapi Clarissa merasa sangat mencintai Arka. Hal itu terlihat dari tiga kutipan berikut.

(1) Kehadiran Arka benar-benar mampu membuatku merasa seperti terlahir kembali. Banyak yang kemudian membuatku merasa bahwa dia memang jodoh yang Tuhan kirimkan, sangat perhatian dan sangat mampu membuatku merasa nyaman. Atau memang seperti inilah yang selalu dirasakan oleh mereka yang kasmaran? (Sempurna: 80).

(2) Sikap Arka yang sangat memanjakanku benar-benar membuaiku. Aku seakan tak butuh lagi kata-kata 'Aku mencintaimu', atau kalimat lainnya karena kini hatiku sudah terisi penuh oleh perhatian yang ia berikan. Arka memang sangat pandai membuatku merasa diperhatikan, ia yang juga kadang memberi kejutan buatku semakin meyakinkanku bahwa cinta bukanlah tentang kalimat puitis atau hal lainnya, tapi lebih ke perhatian dan sikap yang justru sangat romantis (Sempurna: 81).
(3) Hari terus berlalu dan kini semuanya terlihat sempurna. Arka semakin sering mengajakku pergi, dan kami pun sudah terbiasa menghabiskan malam hingga kadang pulang larut sekadar untuk menikmati makan malam atau menonton film. Semua hal baru itu benar-benar menyihirku menjadi pribadi yang baru (Sempurna: 95).

Arka merupakan sosok laki-laki yang mampu mengubah hidup Clarissa menjadi lebih berwarna. Apalagi sebelumnya, Clarissa pernah disakiti oleh laki-laki sehingga Clasrissa merasa bersyukur bisa bertemu dengan Arka. Arka mampu membuat Clarissa bangkit dari rasa sakit hatinya hingga Clarissa bisa membuka hati untuk Arka. Clarissa sangat mencintai Arka, dan dia merasa bahwa Arka memang jodohnya. Hal ini menunjukkan adanya relasi tokoh lakilaki terhadap tokoh perempuan melalui cinta mampu mengubah segalanya.

3) Terluka Kembali

Clarissa merasa bahwa Arka adalah jodoh yang Tuhan kirimkan, tetapi itu salah. Clarissa menemukan foto Arka dengan wanita lain di mobilnya. Sejak saat itu Clarissa merasa sangat kecewa pada Arka, hati Clarissa terluka kembali. Hal itu terlihat dari tiga kutipan berikut.

(1) Sejak menemukan foto Arka sedang mencium pipi gadis lain, aku benar-benar merasa sangat sakit. Malam-malamku kembali dipenuhi air mata dan kesunyian, aku tak tahu apa memang semuanya layak untukku atau memang aku ditakdirkan akan terus menderita dalam cinta (Sempurna: 104). 
(2) Meski mencoba memelankan suaranya, namun aku masih bisa mendengar jelas apa yang dikatakan oleh Arka. Hal ini rasanya sangat sakit, seakan ada pisau berkarat yang menyayat pelan. Tanganku bergetar hebat, air mata perlahan menggumpal di kedua sudut mata. Aku segera berjalan menuju ke dalam kamar, berbaring pura-pura tertidur lelap meski air mata kini tak mampu kutakan menetes dari sudut mata (Sempurna: 123).

(3) Hari-hari yang awalnya terasa sempurna kini berisi pertengkaran yang hebat antara aku dan Arka. Aku benar-benar tak mampu memaafkan sikapnya yang begitu jelas masih menjalin hubungan dengan perempuan lain, yang ternyata tunangannya sendiri. Bagaimana mungkin aku harus percaya pada lelaki yang nyata-nyata sudah memiliki tunangan sementara ia bilang mencintaiku dan ingin mengakhiri pertunangannya? (Sempurna: 124).

Clarissa begitu mencintai Arka sehingga dia merasa bahwa Arka adalah jodohnya, tetapi Tuhan menunjukkan bahwa Arka bukanlah laki-laki yang baik untuk Clarissa. Setelah kejadian itu, hati Clarissa hancur kembali, dia merasakan luka yang sebelumnya sudah pulih. Ketiga data di atas menunjukkan kejadian yang membuat hati Clarissa merasakan sakit lagi. Pada data nomor (1) Clarissa menemukan foto Arka dengan wanita lain di mobilnya, data pada nomor (2) menggambarkan perasaan Clarissa yang sakit hati, dan data pada nomor (3) menunjukkan bahwa wanita dalam foto itu adalah tunangannya Arka. Clarissa merasa tidak menyangka Arka melakukan itu padanya, padahal Clarissa sudah begitu mencintai Arka, hingga akhirnya Clarissa merasa terluka kembali. Hal ini menunjukkan adanya relasi tokoh laki-laki terhadap tokoh perempuan, bagaimana tokoh perempuan itu sangat menaruh harapan yang besar pada tokoh lakilakinya.

4) Cinta dan Keyakinan

Reza adalah lelaki yang mampu mengubah hidup Clarissa menjadi lebih berwarna. Clarissa merasa bahagia Tuhan pertemukan dengan Reza yang kini menjadi suaminya. Hal itu terlihat dari kutipan berikut.

Melihat senyum yang kau beri untukku hari itu, itu sudah cukup membuatku merasa yakin kau mencintaiku. Aku tak butuh kata-kata, aku butuh bahagia dan aku merasakannya bersamamu, bahagia yang hadir lewat senyuman dari bibir tipismuitu (Sempurna: 179).

Clarissa merupakan sosok wanita yang luar biasa. Awalnya, dia merasa kurang beruntung dalam hal percintaan, tetapi dengan keyakinannya dia percaya bahwa Tuhan akan memberikan yang terbaik untuknya. Kisah cinta yang berliku tidak membuatnya hancur, justru dia jadikan setiap luka itu sebagai langkah awal untuk menemukan belahan jiwanya. Benar saja, akhirnya Clarissa bertemu dengan Reza hingga akhirnya mereka memutuskan untuk menikah dan hidup bahagia. Hal itu menunjukkan relasi tokoh laki-laki terhadap tokoh perempuan, bagaimana laki-laki tersebut bisa berpengaruh dalam hidup tokoh perempuan. 


\section{Eksistensi Tokoh Perempuan}

1) Perempuan yang Mandiri dan Pekerja Keras

Clarissa merupakan tokoh utama dalam novel ini. Dia adalah wanita karier yang mandiri, karena sejak kecil dia dididik untuk mandiri dan tidak menyusahkan banyak orang. Hal itu terlihat dari kutipan berikut.

Banyak yang bilang itu semua karena aku terlalu sibuk bekerja dan meraih karier. Tentu saja aku harus bekerja bukan? Aku anak ketiga dari empat bersaudara yang semuanya lelaki. Sejak kecil aku dididik untuk bisa mandiri, bahkan ketika aku berhasil meraih beasiswa untuk kuliahku di Australia, aku melakukan semuanya sendiri (Sempurna: 8).

Clarissa merupakan wanita yang mandiri, dia tidak menggantungkan hidupnya pada orang lain. Meskipun dia wanita, tetapi tidak membuatnya hanya cukup berdiam diri di rumah. Dia memilih untuk menjadi wanita karier. Terlebih, dari kecil dia sudah dibiasakan untuk hidup mandiri. Hal ini menunjukkan eksistensi perempuan bahwa perempuan juga mampu bekerja, tidak hanya laki-laki saja. Apalagi, Clarissa ini wanita yang mandiri dan pekerja keras. Tokoh Clarissa yang mandiri dan pekerja keras juga terlihat dalam kutipan berikut.

Banyak yang bilang kalau aku sebaiknya fokus mengelola cafe yang kubangun itu, bukan lalu malah fokus menjadi redaktur sebuah majalah. Namun, kadang mereka yang mengatakan itu tak memahami nikmatnya bekerja dengan berdiri menatap jendela dunia yang terbuka. Bagiku, selalu ada kepuasan tersendiri saat menemukan pengetahuan baru dan apa saja yang aku baca setiap hari dan ini tentu saja tidak bisa kunikmati jika aku fokus pada cafe. Secara penghasilan, tentu saja pendapatan dari cafe jauh lebih tinggi, namun aku tetap memilih fokus pada majalah dan menyerahkan cafe pada orang yang aku percaya (Sempurna: 36).

Kutipan di atas menunjukkan bahwa Clarissa memang sosok wanita yang mandiri dan pekerja keras. Clarissa lebih memilih untuk mengeksplor dirinya dengan menjadi redaktur di sebuah majalah dibandingkan dengan mengelola cafe yang sebelumnya dia bangun. Clarissa selalu ingin mencoba hal-hal baru untuk menambah pengalaman hidupnya. Hal ini menggambarkan bahwa Clarissa adalah sosok wanita yang luar biasa, dia tidak cepat merasa puas dengan apa yang sudah dia dapatkan tetapi dia malah mencoba hal baru yang sesuai dengan keinginannya.

2) Perempuan yang Kuat

Clarissa merasa hidupnya kurang beruntung dalam hal percintaan. Kini Clarissa tak lagi dekat dengan Arka setelah mengetahui bahwa foto yang ada dimobilnya adalah Arka dengan tunangannya. Ya, ternyata Arka sudah memiliki tunangan dan berniat untuk mengakhiri hubungan dengan tunangannya agar bisa bersama dengan Clarissa. Dengan tegas, Clarissa menolak. Clarissa mencoba untuk bangkit dari kesedihan ini. Hal itu terlihat dari kutipan berikut.

Merasakan pengkhiatan yang begitu hebat seperti ini memang bukanlah hal yang aku impikan saat mulai berani membuka hatiku untuk mencintai dan menerima kehadiran lelaki dalam 
hidupku, namun semua sudah terjadi dan aku tak tahu apa aku harus duduk merenung setiap hari atau aku akan mampu kembali berdiri tegar dan membuka hatiku lagi (Sempurna: 125).

Clarissa merasakan kisah cintanya begitu berliku. Walaupun awalnya Clarissa sangat mencintai Arka, tetapi setelah Arka menyakiti hatinya, Clarissa dengan tegas menolak Arka kembali. Sebisa mungkin Clarissa harus bangkit dari kesedihannya. Hal ini menunjukkan eksistensi tokoh perempuan yang tidak selalu bergantung pada tokoh laki-laki. Clarissa dengan ikhlas melepas Arka dengan harapan kelak dia akan mendapatkan yang lebih baik dari Arka.

3) Perempuan yang Teguh Pendirian Clarissa sosok perempuan yang teguh pendirian. Sekali dia disakiti, dia tidak akan semudah itu memaafkan kesalahan lelakinya. Terlebih, apa yang dilakukan Arka sangat menyakiti hatinya. Arka terus saja berusaha agar Clarissa mau memaafkannya, tetapi Clarissa malah semakin tidak suka dengan kelakukan Arka. Hal itu terlihat dari dua kutipan berikut.

(1) Aku masih tak percaya kalau Arka akan membuatku seperti ini. Entahlah, satu hal yang pasti, aku sedang tak ingin bicara dengannya meski hari ini dia sudah meneleponku hampir tiga puluh kali. Tak satu pun kuangkat, juga beberapa pesan darinya yang kubiarkan memenuhi inbox pesan di HP (Sempurna: 104).

(2) Arka masih saja berusaha untuk meyakinkanku bahwa dia memang benar-benar mencintaiku dan memang ingin memutuskan pertunangannya. Mulai dari mengirim email, surat ke kantorku, sampai kadang aku menemukan kertas yang ia selipkan dari bawah pintu apartemen. Aku makin tak suka dengan sikapnya yang justru malah kini seperti anak kecil itu (Sempurna: 139).

Eksistensi tokoh perempuan terlihat dari tindakan yang dia tunjukkan. Clarissa tidak semudah itu menerima Arka kembali. Walaupun Arka begitu berusaha agar Clarissa mau memaafkannya, tetapi Clarissa adalah wanita yang teguh pendirian. Seberapa besar usaha Arka yang mengingkan Clarissa kembali, tetapi saja Clarissa tidak akan kembali pada Arka. Kedua data di atas menunjukkan Arka yang berusaha agar Clarissa mau memaafkannya, tetapi sekeras apapun usaha Arka, Clarissa tetap pada pendiriannya untuk tidak menerima Arka kembali dalam hidupnya. Tindakan yang dilakukan oleh Arka sudah menunjukkan bahwa dia bukanlah yang terbaik untuk Clarissa, dan Clarissa menyadari hal itu sehingga dia teguh pendirian untuk tidak menerima Arka kembali.

4) Perempuan yang Penuh Keyakinan Semenjak berpisah dengan Arka, Clarissa menjadi sangat sedih. Namun, kini dia bertemu dengan Reza yang mampu menghadirkan senyum itu kembali. Kini, Clarissa menjadi perempuan yang kuat, tak ada lagi kesedihan dalam hidupnya. Dia percaya bahwa Tuhan akan memberikan yang terbaik untuknya. Hal itu terlihat dari kutipan berikut.

Pikiranku tak lagi dipenuhi rasa sedih, bahkan kini mulai bersemangat melanjutkan hidupku. Benar kata Reza, kita tak tahu apa yang akan terjadi esok hari, mungkin saja Tuhan sedang menyiapkan hal yang terbaik untukku. Langkah kakiku yang sempat gontai kini 
kembali penuh makna. Aku tak peduli lagi bagaimana rasa sakit di hati ini terus mencoba membuatku rapuh, aku akan bertahan melawannya

(Sempurna: 177)

Clarissa begitu yakin bahwa setiap rasa sakit yang dia rasakan kelak akan berganti menjadi rasa bahagia yang tak terkira. Dengan penuh keyakinan, Clarissa harus bisa melupakan Arka. Walaupun berat, tetapi dia yakin bisa mampu melakukannya. Hal ini menunjukkan eksistensi tokoh perempuan yang selalu berpikir positif dalam menjalani kehidupannya, meskipun dalam keadaan yang sulit.

5) Perempuan yang Percaya Bahwa Tuhan Akan Memberikan yang Terbaik

Clarissa benar-benar perempuan yang kuat, yang sabar menjalani kehidupannya. Setelah disakiti oleh Arka, dia tidak berlarut-larut dalam kesedihan. Dia percaya Tuhan akan memberikan yang terbaik, dan benar saja. Tuhan mengirimkan Reza untuk melengkapi hidupnya, menghapus segala luka yang ada. Hal itu terlihat dari dua kutipan berikut.

(1) Pikiranku tak lagi dipenuhi rasa sedih, bahkan kini mulai bersemangat melanjutkan hidupku. Benar kata Reza, kita tak tahu apa yang akan terjadi esok hari, mungkin saja Tuhan sedang menyiapkan hal yang terbaik untukku. Langkah kakiku yang sempat gontai kini kembali penuh makna. Aku tak peduli lagi bagaimana rasa sakit di hati ini terus mencoba membuatku rapuh, aku akan bertahan melawannya (Sempurna: 177).

(2) Terkadang apa yang kita inginkan memang tak selamanya bisa kita dapatkan.
Aku tak tahu apa yang salah, namun semua ini membuatku semakin memahami bahwa jodoh bukanlah tentang kapan atau siapa, tetapi tentang kesadaran hati untuk menerima cinta yang hadir. Reza membuatku semakin mengerti, cinta bukan tentang pertemuan terkadang cinta juga terasa begitu kuat saat jarak hadir (Sempurna: 177).

Clarissa adalah wanita yang luar biasa. Dia percaya dibalik rasa sakit hatinya, Tuhan telah menyiapkan sesuatu yang lebih baik dari apa yang dia inginkan. Hingga akhirnya dia bertemu dengan Reza, seseorang yang telah Tuhan siapkan untuk melengkapi hidup Clarissa. Hal ini menunjukkan eksistensi tokoh perempuan yang telah melewati kisah cinta yang panjang hingga akhirnya bertemu dengan jodoh yang telah Tuhan siapkan.

\section{SIMPULAN}

Berdasarkan hasil analisis dapat disimpulkan bahwa kajian feminism merupakan kajian yang membahas mengenai perempuan, yaitu bagaimana perempuan melawan ketidakadilan dalam hidupnya. Kajian feminism salah satunya kajian yaitu feminism eksistensialis. Dalam penelitian ini, mengkaji novel Sempurna karya Novanka Raja menggunakan pendekatan femisme eksistensialis. Dalam novel ini diceritakan bagaimana kisah cinta tokoh utama perempuan bernama Clarissa dan lika-liku kisah cintanya.

Adapun yang dibahas dalam penelitian ini, yaitu relasi kuasa tokoh perempuan dan laki-laki serta eksistensi tokoh perempuan. 


\begin{tabular}{|l|l|}
\hline $\begin{array}{l}\text { BAHTERA INDONESIA: } \\
\text { Jurnal Penelitian Pendidikan Bahasa dan Sastra Indonesia }\end{array}$ & $\begin{array}{l}\text { ISSN 2541-3252 } \\
\text { Vol. 5, No. 2 Sep. } 2020\end{array}$ \\
\hline
\end{tabular}

Relasi tokoh laki-laki merupakan Hidayat, Adi Risqy, dkk. 2013.
bagaimana laki-laki tersebut mampu mengubah kehidupannya, seperti 1) cinta mampu mengubah penampilan diri; 2) cinta mampu mengubah segalanya; 3) terluka kembali; 4) cinta dan keyakinan. Sedangkan eksistensi perempuan merupakan bagaimana perempuan tersebut bias bereksistensi, yang sadar akan dirinya dan tahu cara menempatkan dirinya, meliputi 1)perempuan yang mandiri dan pekerja keras; 2)perempuan yang kuat; 3)perempuan yang teguh pendirian; 4) perempuan yang penuh keyakinan; 5) perempuan yang percaya bahwa Tuhan akan memberikan yang terbaik.

\section{DAFTAR PUSTAKA}

Dina, Farah, dkk. 2013. Representasi Ideologi Patriarki dalam Novel Tanah Tabju Kajian Femisme Radikal. Jurnal Sastra Indonesia. 2, (1), hlm. 1-6.

Fakih. Mansoer. 2001. Analisis Gender dan Transformasi Sosial. Yogyakarta: PustakaPelajar. Representasi Perempuan dalam Novel Supernova-Petir karya Dewi Lestari : Kajian Feminisme Eksistensialis. Repository UNEJ http://repository.unej.ac.id/handle/1 $\underline{23456789 / 60803}$

Maksum, Ali. 2014. Pengantar Filfasat: Dari Masa Klasik Hingga Postmoderisme. Yogyakarta: ArRuzz Media.

Priyatni. Endah Tri. 2015. Membaca Sastra dengan Ancangan Literasi Kritis. Jakarta: PT Bumi Aksara.

Raja, Novanka. 2016. Sempurna. Jakarta: Euthenia.

Ratna, Nyoman Kutha. 2007. Teori, Metode, dan Teknik Penelitian Sastra. Yogyakarya: Pustaka Pelajar.

Sugiyono. 2015. Metode Penelitian Pendidikan. Bandung: Alfabeta.

Suhar, AM. 2010. Filsafat Umum Konsepsi, Sejarah dan Aliran. Jakarta: GaungPersada Press. 